\title{
BACTERIAL STATUS AND POLLUTION LEVEL IN THE SEDIMENT OF GULSHAN LAKE, DHAKA
}

\author{
MD. ABDUL KARIM*, NAZNEEN AKHTER AND SIRAJUL HOQUE ${ }^{1}$ \\ Department of Botany, University of Dhaka, Dhaka 1000 \\ ${ }^{1}$ Department of Soil, Water and Environment, University of Dhaka, Dhaka 1000
}

\begin{abstract}
Gulshan-Baridhara lake located in and around Gulshan, Banani and Baridhara, has always been Dhaka's most exclusive residential area mainly because of the pristine lake. The lake is elongated in a north south direction and surrounded mainly by residential areas and some industrial units as well. To evaluate the pollution level of the sediment of the lake, samples were collected from 4 selected locations in 4 different seasons. Four different media were used to study the aerobic heterotrophic, enteric and related bacterial count. Aerobic heterotrophic bacterial count was in the range of $1.1 \times 10^{4}$ to $1.2 \times 10^{6}$ $\mathrm{cfu} / \mathrm{g}$ in sediment sample, while enteric and related bacterial count in 3 different media (SS agar, MacConkey agar and Cetrimide agar) were $1 \times 10^{0}$ to $1.5 \times 10^{4} \mathrm{cfu} / \mathrm{g}, 1 \times 10^{0}$ to $6 \times 10^{4}$, and $1 \times 10^{0}$ to $1.1 \times 10^{3} \mathrm{cfu} / \mathrm{g}$ in sediment, respectively. Out of 23 bacterial isolates 18 were Gram-positive and 5 were Gram-negative. Among the Gram-positive, all were rod shaped spore former and under the genus Bacillus. Out of 5 Gram-negative isolates 2 were the member of Pseudomonas, remaining 3 strains were Escherichia, Aeromonas and Enterobacter. Total nitrogen and phosphorus level along with the presence of different bacterial strains clearly indicated that Gulshan lake sediment was polluted with the chemical and bacterial pollutants.
\end{abstract}

Key words: Heterotrophic bacteria, Enteric bacteria, Physical and chemical pollution, Lake sediment

\section{Introduction}

The most common aquatic systems of Bangladesh are ponds, rivers, beels, haors, baors and lakes which are great fresh water resources upon which people depend directly or indirectly. This resource has come down much lower value because of over population, urbanization, industrialization and pollution. Pollution can be caused by wide variety of inorganic and organic compounds and microorganisms often play major role in determining the extent of the pollution (Higgins and Burns 1975). Organic pollution occurs when large quantities of organic compounds are released into water. Organic pollutant consists of protein, carbohydrate, fats and nucleic acids which originate from domestic sewage, urban runoff, industrial effluents etc. and act as a substrate for microorganisms (Mason 2002). Godfree et al. (1997) mentioned that fecal streptococci

\footnotetext{
${ }^{*}$ Corresponding author: Email: makarim10@yahoo.com
} 
are the indicator of fecal contamination in water. Indicator microorganisms such as total coliform, fecal coliform and fecal streptococci have been used as a model for the potential presence of pathogenic microorganisms (Patra et al. 2009). Factors responsible for the imbalance of lake are direct discharge of untreated sewage and dumping of solid wastes into the lake; surface runoff during the rainy season that carries pollutants from the catchment areas of the lake, fragmentation of lake by culverts that hinders free movement of water and lack of effective conservation activities of the lake etc. As a result water of the lake become polluted and probable cause of death of fishes, formation of algal bloom and ultimate goal of those decaying substrates into the underneath sediment. Considering above situation and facts, present work was undertaken to determine aerobic heterotrophic, enteric and related bacteria to the context of biological pollution level along with physical and chemical properties to reveal an overall status of pollution of the sediment of Gulshan lake.

\section{Materials and Methods}

Sediment samples were collected by using Ekman-Birge grab sampler and put into clean glass containers from four different sites (GL-1, GL-2, GL-3 and GL-4) of the lake and were carried to the laboratory within a hour of sampling. Sampling site GL-1 is situated near a culvert, where mixing of water of the lake takes place, while GL-2 is near the residential area, where people are crossing lake by boat. The site GL-3 is also near the residential area, where floating people use to bath, swim and wash clothes and GL-4 is near a slum.

Nutrient agar (NA) medium was used for the enumeration and isolation of aerobic heterotrophic bacteria. MacConkey agar (Difco), SS agar (Diagnostic Pasteur) and Cetrimide agar (Difco) media were used for the determination and isolation of enteric bacteria. The $\mathrm{pH}$ of the isolation media was adjusted to 7.2 before sterilization, since the $\mathrm{pH}$ values of most of the samples were within the range of 6.81 to 7.83 . Two different techniques viz. serial dilution plate (Clesceri et al. 1998) and spread plate (Sharp and Lyles 1969) were used for the enumeration and isolation of bacteria. Inoculated bacterial plates were inverted and incubated at $37^{\circ} \mathrm{C}$ for 24 hours.

Bacterial colony counting was made with the help of a digital colony counter (OSK 10086, DC-3, Kayagaki, Japan). Discrete bacterial colonies were isolated immediately after counting. In case of MacConkey agar medium, pink or brick red colonies were considered as lactose fermenter and colorless colonies as non-lactose fermenter. Important physiological and biochemical characteristics were studied for the identification of the selected isolates. Different biochemical tests, viz. catalase, oxidase, carbohydrate fermentation, deep glucose agar, tyrosine degradation, egg-yolk lecithinase, arginine hydrolysis, casein hydrolysis, starch hydrolysis, gelatin hydrolysis, protease, urease, Kligler's iron agar (KIA), Levan, methyl red, nitrate reduction, indole 
production, phenylalanine deamination, citrate utilization, utilization of propionate, Voges-Proskauer (V.P) test etc. were carried out. Bergey's Manual of Systematic Bacteriology (Sneath et al. 1986) was followed for the identification of Gram-positive aerobic heterotrophic bacterial isolates, while Manual for Laboratory Investigations of Acute Enteric Infections (WHO 1987) and Bergey's Manual of Systematic Bacteriology (Krieg and Holt 1984) were used for identifying enteric and related bacteria.

Temperature of sediment samples was measured at the time of sampling with the help of a mercury thermometer. The $\mathrm{pH}$ of collected sediment sample (ratio between sediment: water) was measured by using a digital pH meter (Jenway 3310, UK) immediately after carrying the samples in the laboratory. Total nitrogen present in sediment sample was determined by modified Kjeldahl's method (Kjeldahl 1883, Bremner 1965). Total phosphorus and soluble reactive phosphorus were determined by ascorbic acid blue color method (Murphy and Riley 1962).

\section{Results and Discussion}

The physical properties of the sediment samples are presented in Table 1 . In summer the sediment temperature ranged from 21 to $23.2^{\circ} \mathrm{C}$, while in rainy season that was $24.5^{\circ} \mathrm{C}$. In winter the temperature ranged 10.5 to $11.3^{\circ} \mathrm{C}$ and in late autumn it was found to be between 17.3 and $19.3^{\circ} \mathrm{C}$. The result indicated a favourable temperature for bacterial growth except in winter. The $\mathrm{pH}$ of the sediment samples ranged between 7.16 and 7.72 in summer, 6.81 and 7.31 in rainy season, 7.08 and 7.83 in winter and 6.81 and 7.54 in late autumn. The maximum $\mathrm{pH}$ (7.83) was found in the sample GL-2 in winter, while the minimum $\mathrm{pH}$ (6.81) was found both in the sample GL-2 of rainy season and in the sample GL-4 of late autumn (Table 1). The maximum total nitrogen (1.34\%) was found in GL-2, while minimum $(0.14 \%)$ was in the sample GL-4 during winter (Table 2). Higher concentration of total phosphorus $(0.23 \%)$ was observed in the sample GL-4, while lowest value $(0.13 \%)$ was in the sample GL-1 during winter (Table 2$)$. The higher concentration of soluble reactive phosphorus in the sediment $(22.0 \mu \mathrm{g} / \mathrm{g})$ was recorded in the sample GL-4, while lower $(12.0 \mu \mathrm{g} / \mathrm{g})$ was found in GL-1.

Table 1. Average temperature and pH of the sediment samples.

\begin{tabular}{ccccccccc}
\hline \multirow{2}{*}{$\begin{array}{c}\text { Sampling } \\
\text { location }\end{array}$} & \multicolumn{2}{c}{ Summer } & \multicolumn{3}{c}{ Rainy season } & \multicolumn{2}{c}{ Winter } & \multicolumn{2}{c}{ Late autumn } \\
\cline { 2 - 8 } & $\begin{array}{c}\text { Temperature } \\
\left({ }^{\circ} \mathrm{C}\right)\end{array}$ & $\mathrm{pH}$ & $\begin{array}{c}\text { Temperature } \\
\left({ }^{\circ} \mathrm{C}\right)\end{array}$ & $\mathrm{pH}$ & $\begin{array}{c}\text { Temperature } \\
\left({ }^{\circ} \mathrm{C}\right)\end{array}$ & $\mathrm{pH}$ & $\begin{array}{c}\text { Temperature } \\
\left({ }^{\circ} \mathrm{C}\right)\end{array}$ & $\mathrm{pH}$ \\
\hline GL-1 & 22.6 & 7.72 & 23.6 & 7.19 & 11.3 & 7.08 & 18.2 & 7.10 \\
GL-2 & 21.0 & 7.54 & 23.9 & 6.81 & 10.5 & 7.83 & 17.3 & 7.26 \\
GL-3 & 23.2 & 7.16 & 24.5 & 6.94 & 11.1 & 7.24 & 19.3 & 7.54 \\
GL-4 & 23.0 & 7.65 & 24.0 & 7.31 & 10.5 & 7.61 & 19.0 & 6.81 \\
\hline
\end{tabular}


In the present study, the value of total amount of nitrogen and phosphorus were higher in comparison with the guidelines recommended by USPH (Table 2).

Table 2. Average chemical variables of sediment samples in winter season.

\begin{tabular}{ccccc}
\hline \multirow{2}{*}{$\begin{array}{c}\text { Sampling } \\
\text { location }\end{array}$} & Nitrogen & & \multicolumn{2}{c}{ Phosphorus } \\
\cline { 2 - 2 } \cline { 4 - 5 } \cline { 4 - 5 } & Total $(\%)$ & & Total $(\%)$ & Soluble $(\mu \mathrm{g} / \mathrm{g})$ \\
\hline GL-1 & 0.69 & & 0.13 & 12.0 \\
GL-2 & 1.34 & & 0.20 & 21.0 \\
GL-3 & 1.14 & & 0.19 & 12.5 \\
GL-4 & 0.14 & & 0.23 & 22.0 \\
\hline
\end{tabular}

The aerobic heterotrophic and enteric bacterial counts of sediment samples are shown in Table 3. Maximum aerobic heterotrophic bacterial load $\left(1.2 \times 10^{6} \mathrm{cfu} / \mathrm{g}\right)$ was in GL-1 during rainy season, while minimum $\left(2.3 \times 10^{3} \mathrm{cfu} / \mathrm{g}\right)$ was in GL-2 during winter. Bacterial growth on MacConkey agar ranged between $1 \times 10^{1} \mathrm{cfu} / \mathrm{g}$ and $6 \times 10^{4} \mathrm{cfu} / \mathrm{g}$, where maximum colonies were observed in sample GL-2 during summer and minimum in GL-4 during winter, while no growth was observed in GL-3 of rainy season, GL-2 of late autumn and GL-3 of winter. The highest number of bacterial colonies on SS agar was

Table 3. Bacterial count (cfu/g) of sediment samples.

\begin{tabular}{|c|c|c|c|c|c|}
\hline \multirow{2}{*}{$\begin{array}{c}\text { Sampling } \\
\text { location }\end{array}$} & \multirow{2}{*}{$\begin{array}{c}\text { Aerobic } \\
\text { heterotrophic } \\
\text { bacteria }\end{array}$} & \multicolumn{3}{|c|}{ Enteric and related bacteria on } & \multirow{2}{*}{$\begin{array}{c}\text { Total bacterial } \\
\text { load }\end{array}$} \\
\hline & & MacConkey agar & SS agar & Cetrimide agar & \\
\hline \multicolumn{6}{|c|}{ Summer } \\
\hline GL-1 & $3.9 \times 10^{5}$ & $8 \times 10^{3}$ & $1.0 \times 10^{4}$ & - & $4.1 \times 10^{5}$ \\
\hline GL-2 & $9.3 \times 10^{5}$ & $6 \times 10^{4}$ & $1.5 \times 10^{4}$ & - & $1.0 \times 10^{6}$ \\
\hline GL-3 & $5.1 \times 10^{5}$ & $3 \times 10^{4}$ & $3.9 \times 10^{3}$ & - & $5.5 \times 10^{5}$ \\
\hline GL-4 & $5.3 \times 10^{5}$ & $1 \times 10^{4}$ & $3.3 \times 10^{3}$ & $1.1 \times 10^{3}$ & $5.4 \times 10^{5}$ \\
\hline \multicolumn{6}{|c|}{ Rainy Season } \\
\hline GL-1 & $1.2 \times 10^{6}$ & $7.4 \times 10^{3}$ & $5.4 \times 10^{2}$ & - & $1.2 \times 10^{6}$ \\
\hline GL-2 & $6.0 \times 10^{5}$ & $3.7 \times 10^{3}$ & $1.8 \times 10^{4}$ & $1 \times 10^{2}$ & $6.2 \times 10^{5}$ \\
\hline GL-3 & $3.0 \times 10^{5}$ & - & - & - & $3.0 \times 10^{5}$ \\
\hline GL-4 & $4.0 \times 10^{5}$ & $9.8 \times 10^{3}$ & $1.0 \times 10^{4}$ & - & $4.2 \times 10^{5}$ \\
\hline \multicolumn{6}{|c|}{ Late Autumn } \\
\hline GL-1 & $1.02 \times 10^{5}$ & $2.0 \times 10^{1}$ & - & $2.2 \times 10^{1}$ & $1.0 \times 10^{5}$ \\
\hline GL-2 & $2.0 \times 10^{4}$ & - & - & $8.7 \times 10^{1}$ & $2.0 \times 10^{4}$ \\
\hline GL-3 & $2.0 \times 10^{4}$ & $3.0 \times 10^{1}$ & - & - & $2.0 \times 10^{4}$ \\
\hline GL-4 & $8.0 \times 10^{3}$ & $7.0 \times 10^{1}$ & - & - & $8.0 \times 10^{3}$ \\
\hline \multicolumn{6}{|c|}{ Winter } \\
\hline GL-1 & $1.1 \times 10^{4}$ & $2.0 \times 10^{1}$ & - & $0.4 \times 10^{1}$ & $1.1 \times 10^{4}$ \\
\hline GL-2 & $2.3 \times 10^{3}$ & $2.0 \times 10^{2}$ & - & $1.0 \times 10^{1}$ & $2.3 \times 10^{3}$ \\
\hline GL-3 & $5.0 \times 10^{4}$ & - & - & $0.2 \times 10^{1}$ & $5.0 \times 10^{4}$ \\
\hline GL-4 & $2.0 \times 10^{4}$ & $1.0 \times 10^{1}$ & - & - & $2.0 \times 10^{4}$ \\
\hline
\end{tabular}

$"$ - " = No colony. 


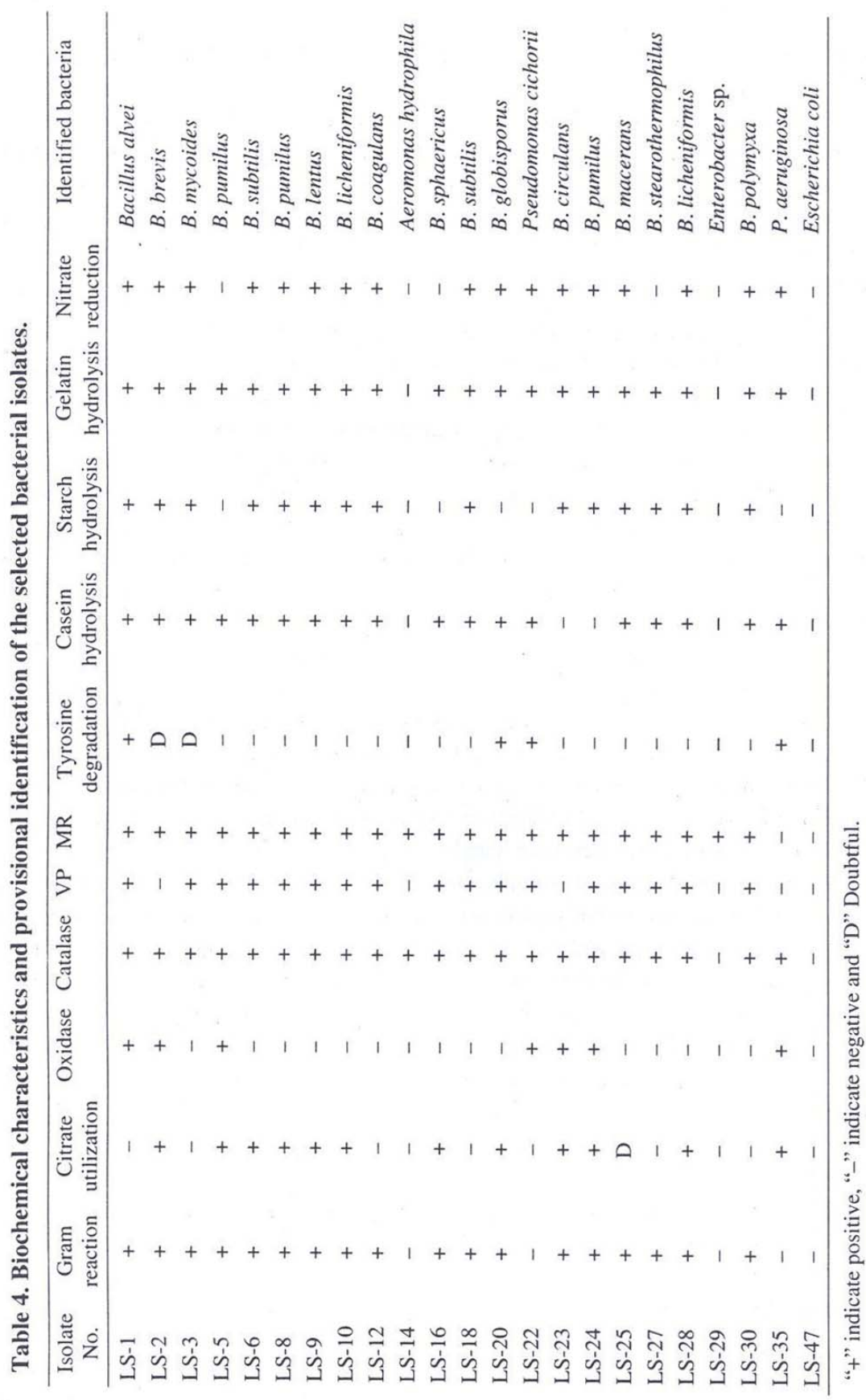


found in GL-2 during rainy season and it was $1.8 \times 10^{4} \mathrm{cfu} / \mathrm{g}$, while the lowest count $\left(5.4 \times 10^{2} \mathrm{cfu} / \mathrm{g}\right)$ was found in GL-1 during same season. However, no growth was found in GL-3 of rainy season and all sites of both late autumn and winter. Furthermore, bacterial growth on cetrimide agar ranged between $0.2 \times 10^{1} \mathrm{cfu} / \mathrm{g}$ and $1.1 \times 10^{3} \mathrm{cfu} / \mathrm{g}$, where maximum colonies were found in GL-4 during summer and minimum was in GL3 during winter (Table 3). No colonies were grown on cetrimide agar in GL-1, GL-2 and GL-3 during summer; in GL-1, GL-3 and GL-4 during rainy season; in GL-3 and GL-4 during late autumn and in GL-4 during winter (Table 3).

During this investigation, out of 80 isolates, 23 were randomly selected and purified for provisional identification. Selected isolates were identified on the basis of their morphological characters, gram reaction and necessary biochemical tests (Table 4). Among these 18 were Gram-positive and remaining 5 were Gram-negative. Among the Gram-positive, 18 isolates were rod shaped, spore former and members of the genus Bacillus. Under the genus Bacillus there were 14 distinct species viz. B. alvei, B. brevis, B. mycoides, B. pumilus (3), B. subtilis (2), B. lentus, B. licheniformis (2), B. coagulans, $B$. sphaericus, $B$. globisporus, B. circulans, B. macerans, $B$. stearothermophilus and $B$. polymyxa. Enteric bacteria were Gram-negative, short rod and non-spore former. Five Gram-negative bacterial isolates were under the genus Pseudomonas (2), Escherichia, Aeromonas and Enterobacter (Table 4). The load of aerobic heterotrophic bacteria and abundance of coliform and fecal coliform group in the sediment clearly showed significant level of microbial pollution of the lake. The coliform group of bacteria including aerobic and facultative anaerobic bacilli that produce acid and gas from the fermentation of lactose includes Escherichia coli and Enterobacter aerogenes (Maier et al. 2000). Both of E. coli and Enterobacter sp. were present in the lake sediment sample. Psudomonas aeruginosa has been employed as sewage indicator, while Aeromonas hydrophila as an indicator of eutrophication (Bahlaoui et al. 1997). Presence of E. coli and Pseudomonas sp. in the present study clearly indicates that the lake sediment is contaminated with fecal and sewage pollution. The lake is being used for bathing, washing and swimming by the floating people living along the lake side, which is likely to be infected with these types of pathogens and this may the cause of diseases like diarrhoea, typhoid, dysentery etc. Furthermore, cultivated fish could also be infected by those pathogens and ultimately might be transmitted to the people and can cause such diseases.

\section{References}

Bahlaoui, M.A., B. Baleux and M. Troussellier. 1997. Dynamics of pollution-indicator and pathogenic bacteria in high-rate oxidation wastewater treatment ponds. Wat. Res. 31(3): 630-638.

Bremner, J.M. 1965. Total nitrogen. In: Methods of soil analysis, Part 2. C.A. Black et al. (eds.). Am. Soc. Agron., Inc., Madison. 9: 1149-1178. 
Clesceri, L.S., A.E. Greenberg and A.E. Eaton (eds.). 1998. Standard Methods for Examination of Water and Wastewater (20 $0^{\text {th }}$ Ed.). American Public Health Association, American Water works Association and the Water Environment Federation, Washington. pp. 1220.

Godfree, A.F., D. Kay and M.D. Wyer. 1997. Faecal streptococci as indicators of faecal contamination in water. Soc. Appl. Bacteriol. Symp. Ser. 26: 110S-119S.

Higgins, I.J. and R.G. Burns. 1975. The Chemistry and Microbiology of Pollution. Academic Press, London. 8: 256.

Kjeldahl, J. 1883. Neue methode zur Bestimmung des Stickstoffs on organischen Krpern. Z. Anal. Chem. 22: 366-382.

Krieg, N.R. and J.G. Holt (eds.). 1984. Bergey's Manual of Systematic Bacteriology (Vol. 1). The Williams and Wilkins Company, Baltimore, USA. pp. 1-964.

Maier, R.M., I.L. Pepper and C.P. Gerba. 2000. Environmental Microbiology. Academic Press, California, USA. pp. 491-503.

Mason, C.F. 2002. Biology of fresh water pollution (4 ${ }^{\text {th }}$ Ed.). Prentice-Hall, Harlow. pp. 1-387.

Murphy, J. and J.P. Riley 1962. A modified single solution method for determination of phosphate in natural water. Anal. Chem. Acta. 27: 31-36.

Patra, A.K., B.C. Acharya and A. Mohapatra. 2009. Occurrences and distribution of bacterial indicator and pathogens in coastal waters of Orissa. Ind. J. Mar. Sci. 38(4): 474-480.

Sharp, M.S. and S.T. Lyles. 1969. Laboratory instruction in biology of microorganisms. Saint Louis the C V Mosley Company. pp. 23-25.

Sneath, P.H.A., N.S. Mair, M.E. Sharpe and J.G. Holt (Eds.). 1986. Bergey's manual of systematic bacteriology $\left(9^{\text {th }}\right.$ Ed.). Vol. 2. The Williams and Wilkins Co., Baltimore, USA. pp. $965-$ 1594.

WHO. 1987. Manual for laboratory investigations of acute enteric infections. CDD/83.3 Rev.1. Geneva: World Health Organization. pp. 109-111. 